\title{
REVIEW
}

\section{Forensic identification of fish farm escapees: the Norwegian experience}

\author{
Kevin A. Glover* \\ Institute of Marine Research, PO Box 1850, 5817 Nordnes, Bergen, Norway
}

\begin{abstract}
Aquaculture management authorities require the ability to identify the farm of origin for escaped fish. Physical tagging is routinely conducted for domesticated animals (e.g. sheep and cattle); however, there are considerable logistical, animal welfare and economic issues that challenge the feasibility of physically tagging all farmed fish. A 'DNA stand-by method' for identification of escaped Atlantic salmon, back to the cage and farm of origin, was established at the Institute of Marine Research in Norway. In addition, proof-of-concept for the method has been demonstrated to be able to trace rainbow trout and Atlantic cod escapees back to their farm source. The combined sampling, genotyping and statistical analysis on which the method is based has been implemented successfully in the identification of fish farm escapees in Norway, resulting in fines for companies found in breach of regulations. This paper reviews the method, its challenges, and some previously considered alternatives. It is concluded that as the method has been successful for the 3 major species farmed in Norway, each with contrasting production logistics including breeding programs, state of domestication, and magnitude of production, the DNA stand-by method can be applicable to identification of fish farm escapees for a wide range of aquaculture species in all regions of the world.
\end{abstract}

KEY WORDS: Farm escapee · Wildlife forensics $\cdot$ Law enforcement $\cdot$ Genetic assignment

\section{INTRODUCTION}

Aquaculture represents an expanding use of the world's marine ecosystems. In Norway, which is one of the largest global seafood producers, the combined aquaculture production of Atlantic salmon Salmo salar, rainbow trout Oncorhynchus mykiss and Atlantic cod Gadus morhua is worth more than the total catch from wild fisheries, and represents the country's second most economically significant export product.

A major challenge with aquaculture is containment, and in all regions where fish are reared in marine cages escapees are reported. For example, 154466 Atlantic salmon escapees were reported to the authorities in Scotland in 2007 (Anoymous 2007), and in Norway, 921000 Atlantic salmon escapees were reported in 2006 (www. fiskeridir.no/statistikk/akvakultur/roemmingsstatistikk). Genetic changes in wild Atlantic salmon populations, as a result of interbreeding between wild and farmed conspecifics, have been documented (Clifford et al. 1998a,b,
Crozier 2000, Skaala et al. 2006), and it is likely that genetic impacts on wild populations are density dependent (Hindar et al. 2006). Farmed salmon strains display lower levels of genetic variation when compared with wild salmon populations (Norris et al. 1999, Skaala et al. 2004), and display genetic differences for traits such as growth (Thodesen et al. 1999, Glover et al. 2009a), physiology (Johnsson et al. 2001, Fleming et al. 2002), behaviour (Fleming \& Einum 1997) and gene transcription (Roberge et al. 2006, 2008). Furthermore, offspring of farmed fish, and hybrids, display lower fitness in natural habitats when compared to their wild counterparts (McGinnity et al. 1997, 2003, Fleming et al. 2000). Consequently, it is generally accepted that farm escapees represent a significant threat to the genetic integrity, and ultimately, the long-term evolutionary capacity of recipient wild populations.

The numbers of farm escapees needs to be significantly reduced if a sustainable aquaculture industry and healthy wild stocks are to co-exist in the future. 
Fish may escape from marine cages for a variety of reasons, and whilst the number of escapees can be reduced by means of new technological solutions and improved farm management, other causes, such as storms or boating accidents, may be more difficult to guard against. In Norway, and many other countries where marine aquaculture exists, fish-farmers have a legal obligation to report escapees to the authorities. Nevertheless, there is a significant component of underreporting (Baarøy et al. 2004), and there is growing opinion that farmed fish need to be marked by some method in order to identify the source of escapees, and potentially, to allow fish farmers infringing on regulations to be prosecuted.

Application of DNA technologies for identification of fish in food products (Rasmussen \& Morrissey 2008), fisheries enforcement (Ogden 2008) and wildlife forensics in general (Baker 2008) is expanding. A variety of statistical methods can be implemented to support these technologies (Hansen et al. 2001, Manel et al. 2005). Assignment tests, including semi- and fully Bayesian variations involve matching the multilocus genetic profile of an unknown individual or group of individuals to potential source groups or populations. The probability of belonging, or not belonging, can be computed. Individual genetic assignment has been implemented in a range of management applications, for example, illegal animal translocations (Frantz et al. 2006), illegal trade (Wasser et al. 2008) and fraud (Primmer et al. 2000).

In a genetic study of domesticated and wild Atlantic salmon, based upon data from 12 microsatellite loci, large differences were observed between some of the major farmed strains used in Norwegian aquaculture (Skaala et al. 2004). Additionally, these authors demonstrated the ability to accurately identify farmed salmon to the strain of origin. Building on these observations, the farm and exact cage of origin for a group of Atlantic salmon escapees was identified successfully for the first time (Glover et al. 2008). The method was subsequently termed the 'DNA stand-by method' by management authorities in Norway. Further studies have demonstrated proof-of-concept for using the DNA stand-by method to identify the farm of origin for escaped rainbow trout (Glover 2008) and Atlantic cod (Glover et al. in press). In addition, the accuracy of the method has been improved (Glover et al. 2009b, in press).

The DNA stand-by method has been implemented in a number of 'real-life' cases to identify the source of escaped fish back to the farm of origin, as a forensic service for the Norwegian Directorate of Fisheries (NDF), who are responsible for production and implementation of aquaculture regulations. This paper reviews the experience gained through implementation of the method during the period 2006-2009. Chal- lenges, practical considerations and other components central in implementing the method are identified and discussed in order to outline the potential for utilising this, or similar techniques, to identify fish farm escapees in other species and regions of the world.

\section{REVIEW OF THE DNA STAND-BY METHOD}

\section{Background to the DNA stand-by method}

In order to assist with the regulation of aquaculture, the NDF required a tool to identify the farm(s) of origin for escaped Atlantic salmon. This tool would be implemented in cases where a distinct escapement of farmed fish was evident (i.e. a group of escapees are suddenly observed/reported), but no farms within the region reported losses of fish. It is important to note that fish escaping from a farm does not in itself represent a breach of Norwegian aquaculture regulations; however, escapees may be indicative of farm mismanagement. Furthermore, farmers are legally obliged to report all situations in which fish have escaped, even when escapement is not certain. Consequently, the mandate was to develop a reliable method for identifying escapees. Whilst diagnostic identification of source farm(s) was desired, the NDF emphasised that any method that could lead to the exclusion of some farms as potential sources of the escapees would be useful. This would permit fishery officers to inspect the remaining farms that were not excluded as potential sources to look for evidence of escapement and/or mismanagement. Prior to development of the DNA standby method, a committee established by the NDF reviewed a range of approaches to permit identification of escapees back to the farm of origin (Baarøy et al. 2004).

A selection of individual and group tagging systems have been established or adapted for identification of fish in both culture and in the wild. These include external tags (McAllister et al. 1992), in addition to advanced electronic, transponder and radio-based systems (Cookingham \& Ruetz 2008, Campana et al. 2009, Shroyer \& Logsdon 2009). In terrestrial agriculture, physical tags, usually placed in the animal's ear soon after birth, are used widely for documenting both ownership and animal pedigree. It is therefore pertinent to ask whether tagging could provide a universal approach to monitor and identify farmed fish. Physical tagging could be used to identify fish both on the inside of cages to enable farmers to monitor fish movements between production units, and the outside of cages to enable managers to identify escapees. Passive integrated transponder tags are commonly used in aquaculture for broodfish identification (Jackson et al. 2003) and for identification of large numbers of off- 
spring in selection programs (Powell et al. 2008). In addition, coded wire tags have been used extensively for identification of fish groups in the wild (Brennan et al. 2007, Bumgarner et al. 2009). These tagging systems provide identification that could in theory be adapted to mark all fish reared in culture.

Physical tagging offers some advantages over a DNA or chemical-based approach to identification (Table 1). However the Norwegian committee reviewing potential identification methods (Baarøy et al. 2004) concluded that tagging all farmed fish would require extensive development of logistic systems for both marking and tracking the fish 'in and out' for all stages of production. Furthermore, tagging would have animal welfare implications and be prohibitively expensive. Consequently, while individual tagging of all farmed fish potentially represents the most diagnostic identification method, it is unlikely to be imposed on the Norwegian industry within the foreseeable future. As an alternative method, it was concluded that one of the most promising suggestions was the stand-by method which takes advantage of naturally occurring markers (DNA or chemical) within the fish.

\section{Implementation of the DNA stand-by method}

Meeting the needs of the NDF, researchers at the Institute of Marine Research (IMR) developed what is referred to as the DNA stand-by method. This was first implemented in Norway in the autumn of 2006 (Glover et al. 2008). In response to multiple observations of farm escapees by the general public, the NDF secured genetic samples from 32 escaped farmed salmon that had been captured in the Romsdal fjord. Thereafter, the NDF secured samples from all farms in the region that contained fish overlapping in size with the escapees. For farms that reared fish that originated from more than one smolt producer, one sample, consisting of 50 fin clips, was taken from a single cage representing each of these sources. For one farm, this included sampling 5 out of 10 cages in total (250 fish split into 5 independent potential sources for the escapees). Following genotyping with a panel of polymorphic microsatellite markers, the multilocus genetic profile for each of the escapees was then matched (to find the statistical most likely source), and excluded (to identify sources from where it could not have originated at a pre-determined level of significance) to identify the farm of escapement. A single cage on one farm was identified as the most likely source of origin for the majority of the escapees, and the results were used to initiate an investigation by the Norwegian Police for Economic and Environmental Crime (Økokrim). The company was subsequently fined.

In total, the DNA stand-by method has been implemented in 7 cases where the NDF required information on potential source(s) of recaptured farm-escaped fish

Table 1. Key advantages (Pros) and disadvantages (Cons) of physically tagging farmed fish versus implementation of a DNAbased stand-by identification method

\begin{tabular}{|c|c|c|}
\hline & Pros & Cons \\
\hline $\begin{array}{l}\text { Physical marking } \\
\text { (all fish) }\end{array}$ & $\begin{array}{l}\text { Accurate identification } \\
\text { Identification of drip-leakage and large single } \\
\text { escapements } \\
\text { Identification years after escapement (even } \\
\text { when fish farm has slaughtered out production) } \\
\text { Identification of farmed fish in the wild (e.g. } \\
\text { permitting removal from natural populations) }\end{array}$ & $\begin{array}{l}\text { Significant investment in logistics and equipment } \\
\text { Requires extensive documentation and management } \\
\text { from authorities } \\
\text { Tag losses } \\
\text { Large operational costs } \\
\text { Most fish do not escape (wasted efforts?) } \\
\text { Fish welfare (tag wounds, handling) } \\
\text { Depending upon system, tag removal prior to } \\
\text { consumption } \\
\text { When to tag contra when did they escape issues, } \\
\text { e.g. fish marked on Farm A, later sold to Farm B. } \\
\text { Who lost them? }\end{array}$ \\
\hline $\begin{array}{l}\text { DNA } \\
\text { stand-by method }\end{array}$ & $\begin{array}{l}\text { Very low cost } \\
\text { Costs born by 'polluter' rather than entire industry } \\
\text { Does not require investment in equipment } \\
\text { Does not require handling of fish nor adaptation } \\
\text { of physical production procedures } \\
\text { Only requires efforts in response to a real escape- } \\
\text { ment as potential to identify genetic introgression } \\
\text { in wild populations }\end{array}$ & $\begin{array}{l}\text { Not suitable for identification of drip-leakage events } \\
\text { Needs to be rapidly implemented following } \\
\text { escapement } \\
\text { Requires that authorities are on stand-by and have } \\
\text { contacts 'in the field' } \\
\text { Not all cases will lead to diagnostic identification of } \\
\text { single farm }\end{array}$ \\
\hline
\end{tabular}


Table 2. Summary of 6 cases where the DNA stand-by method has been implemented to identify fish farm escapees in Norway. Esc: number of farm escapees analysed; $F_{\mathrm{ST}}$ : range in pair-wise $F_{\mathrm{ST}}$ among farm samples (global $F_{\mathrm{ST}}$ in brackets); Self assign: mean correct self-assignment percentage among farm samples (Geneclass); Escapee assign: percentage of the escapees directly assigned to the 3 most likely farm samples. N/A: not applicable

\begin{tabular}{|c|c|c|c|c|c|c|c|}
\hline Case & Species & Esc & $\begin{array}{l}\text { Farms/cages } \\
\text { sampled }\end{array}$ & $F_{\mathrm{ST}}$ & $\begin{array}{c}\text { Self } \\
\text { assign }(\%)\end{array}$ & $\begin{array}{l}\text { Escapee } \\
\text { assign (\%) }\end{array}$ & Comments \\
\hline 1 & $\begin{array}{l}\text { Atlantic } \\
\text { salmon }\end{array}$ & 29 & $7 / 16$ & $0.001-0.154(0.089)$ & 62.5 & $72,7,7$ & $\begin{array}{l}\text { Single cage and farm identified. Com- } \\
\text { pany subsequently admitted losing fish. } \\
\text { Fined by authorities. }\end{array}$ \\
\hline 2 & $\begin{array}{l}\text { Atlantic } \\
\text { salmon }\end{array}$ & 44 & $7 / 8$ & $0.004-0.101(0.052)$ & 67.2 & $25,22,20$ & $\begin{array}{l}\text { No clear result. Multiple cages, farms } \\
\text { and companies implicated. Case } \\
\text { complicated by presence of fish from } \\
\text { multiple sources. No legal case initiated. }\end{array}$ \\
\hline 3 & $\begin{array}{l}\text { Atlantic } \\
\text { salmon }\end{array}$ & 48 & $7 / 9$ & $0.002-0.117(0.076)$ & 64.8 & $98,2,0$ & $\begin{array}{l}\text { Single cage and farm identified. Rapid } \\
\text { sampling of escapees and differentiated } \\
\text { baseline samples gave distinct result. } \\
\text { Company fined and forced to compen- } \\
\text { sate for analytical costs. }\end{array}$ \\
\hline 4 & $\begin{array}{l}\text { Rainbow } \\
\text { trout }\end{array}$ & 35 & $6 / 7$ & $0-0.127(0.03)^{\mathrm{a}}$ & $82.5^{\mathrm{a}}$ & $91,6,3^{a}$ & $\begin{array}{l}\text { Farm(s) operated by single company } \\
\text { clearly implicated. Only producer in } \\
\text { region. No legal case initiated due to } \\
\text { circumstances unrelated to the method. }\end{array}$ \\
\hline 5 & $\begin{array}{l}\text { Atlantic } \\
\text { salmon }\end{array}$ & 47 & $5 / 7$ & $0.003-0.140(0.075)$ & 63.5 & $89,6,2$ & $\begin{array}{l}\text { Single cage and farm identified. Legal } \\
\text { case in development. }\end{array}$ \\
\hline 6 & $\begin{array}{l}\text { Atlantic } \\
\text { salmon }\end{array}$ & 40 & $1 / 1$ & N/A & N/A & 0 & $\begin{array}{l}\text { Escapees excluded from a farm reported } \\
\text { to have lost fish. This led to sampling } \\
\text { all farms in region to identify the 'un- } \\
\text { reported' source. Case under analysis. }\end{array}$ \\
\hline
\end{tabular}

(Table 2). With one exception (Case 2), all cases lead to a clear conclusion (including Case 7 for Atlantic cod 2009, not presented in Table 2). Thus far, none of the cases have been challenged in a court case, and when given, fines were accepted by the companies.

Case 6 was different from the other cases and was initiated when the NDF received an official report of escapement from a farm in a fjord (reported by the farm's management in accordance with regulations). A few weeks later, the NDF received public reports of farm escapees, of similar size to the reported escapement source, in the outer regions of the same fjord. While it was reasoned that these fish could have originated from the reported escapement, the NDF lacked sightings of these fish between the reported escapement source and the present location of the escapees. In order to clarify this situation, the NDF took samples of both escapees and of fish from the farm that had reported losses of fish. All 40 escapees were excluded from the fish farm sample, demonstrating clearly that this was not the source of these fish. A full case was initiated immediately to find the actual source of the escapees. While the DNA stand-by method was not primarily intended to be applied in this manner, it illustrates the versatility of the method which can provide managers with an identification and monitoring tool.

\section{Conditions for application of the DNA stand-by method}

The DNA stand-by method must fulfill a number of conditions in order to be implemented in a robust manner and, not least, to offer the best possible chance of identifying escapees (Fig. 1). As suggested previously (Glover et al. 2008, 2009b), rapid recapture of a homogenous group of escapees in restricted time and space is the most important step in identification of farm escapees using this method. At any one time, there are hundreds of active salmon farms along the coast of Norway and thousands of farm escapees potentially originating from these sources. Farm-escaped salmon can travel very long distances (Hansen et al. 1997, Milner \& Evans 2003), even over relatively short timeperiods (O. T. Skilbrei unpubl.). Consequently, in order to avoid having to compare the genetic profile of recaptured escapees with every single farm in Norway, which is clearly not feasible, one needs to capture the escapees close to the source of escapement. By doing this, it is possible to restrict sampling to farms within a defined region, while retaining confidence that all potential sources have been sampled.

Sampling of farm escapees is ideally conducted immediately, and certainly within days of their detection. This is important to ensure sampling before the 
Farmed escapees reported to NDF. Numbers, size and location of escapees compared with escapement log. Is this a new or registered escapement?

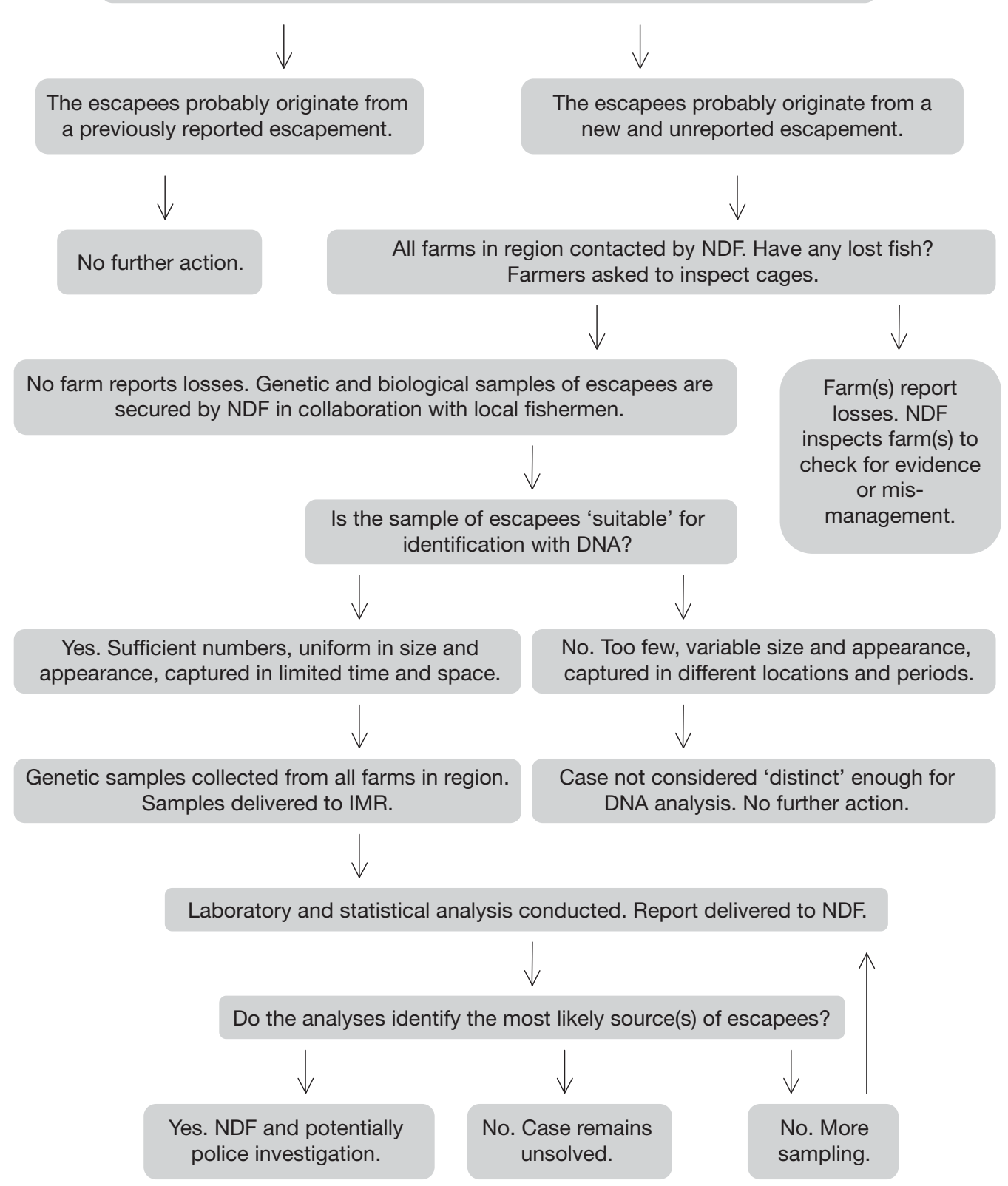

Fig. 1. Logistics between the Norwegian Directorate of Fisheries (NDF) receiving reports of farm escapees in the wild, and implementation of the DNA stand-by method. IMR: Institute of Marine Research

fish disperse from the probable region of escapement and mix with fish from other potential escapement sources. The network of anglers and commercial fishermen in Norway provide a significant informal monitoring of the coastline, and nationally, the NDF receives reports of fish farm escapees on a daily basis. This represents a significant amount of information, which in itself provides considerable challenges (e.g. sorting out reliable information and knowing when to act). Nevertheless, a comparison of new reports of escapees with logged reports from earlier tips from the public provides the NDF with the ability to detect a sudden appearance of fish from a new escapement event. Indeed, in a study of catch per unit effort by hobby net-fishermen, a local escapement of farmed Atlantic salmon was detected readily by a rapid spike in the daily catch in the region (Skilbrei \& Wennevik 2006). 
Supplementary data including escapee size, state of maturity, number of sea lice Lepeophtheirus salmonis L., in addition to location of capture, are important indicators of the likelihood of a group of recaptured escapees having originated from a single source. For example, a group of 20 fish ranging from 0.5 to $6 \mathrm{~kg}$ captured over a period of $4 \mathrm{wk}$ in 3 locations separated by $100 \mathrm{~km}$ is unlikely to have originated from a single cage on a farm. Statistical methods implemented in genetic clustering programs such as Structure 2.0 (Falush et al. 2003) can be, and are, actively used to delineate the number of distinct genetic groups a set of fish farm escapees may be divided into (Glover et al. 2010a in press). Nevertheless, review of available biological (e.g. fish size) and capture data (e.g. date and location) is important in order to avoid wasting resources on diffuse, highly complicated complicated or otherwise unsuitable escapement events for tracing by the method.

In addition to rapid sampling of escapees, location, and to some degree time of year, plays a major role in the probability of being able to make a clear identification of the source of fish farm escapees. Location (region) is important due to the number of farms (and therefore number of potential sources of escapement) and the likelihood of encountering background noise through sampling fish farm escapees from multiple sources. For example, the Hardanger fjord in western Norway represents Norway's most intensive fish farming region, producing approximately 60000 metric t of Atlantic salmon and rainbow trout in 2006. Although it is possible to implement the DNA stand-by method in such a dense farming region (Glover et al. 2009b), this is a large fjord ( $170 \mathrm{~km}$ long), offering considerable potential for the accumulation of escapees from a number of farms.

A significant number of fish farm escapees return to (or never leave) coastal areas in the summer and autumn of each year on their way to entering rivers as part of a spawning migration (Lund et al. 1991, Webb et al. 1991, Crozier 1993, Walker et al. 2006). Clearly, these individuals may have originated from multiple sources (potentially farms located along the entire coastline). In regions with a high density of farms, especially in the summer and autumn months when fish are migrating towards freshwater, successful identification may require a very distinct and sudden increase in the number of escapees in order to gain a good signal (fish originating from the new unreported escapement event) to noise (fish resulting from background escapement) ratio.

When all logistical and sampling requirements are fulfilled (above and Fig. 1), genetic differentiation among samples collected from the potential sources of escapement (cages and farms) represents the primary factor that enables a diagnostic identification of the escapees. Clearly, if farms rear fish of similar genetic background, perhaps sourced from the same hatchery, then the resultant genetic differences will be less than when this is not the case.

\section{Logistics of Atlantic salmon production in Norway}

The logistics of Atlantic salmon production, and flow of genetic material from breeding programs where domestication selection is practiced to commercial producers, is both complicated and dynamic (Fig. 2). Norwegian Atlantic salmon aquaculture is based entirely on domesticated strains, and it is estimated that over $95 \%$ of commercial production is based on fish supplied by 4 breeding companies (Aqua Gen AS, SalmoBreed AS, Marine Harvest [Mowi], and Rauma Gruppen AS). All of the strains maintained by these companies are founded by wild Norwegian salmon, and the origin of genetic material in some of these breeding programs has been reviewed (Gjedrem et al. 1991).

The nature and structure of Norwegian Atlantic salmon breeding programs varies between companies. In addition, this has varied within companies over time. For example, whilst some companies have operated with 4 more or less genetically isolated strains, each with a 4 yr generation time, others have utilised mixed populations maintained by crossing male and female fish of different ages (to avoid crossing siblings when individual pedigree information is lacking). For companies maintaining separate strains, the genetic distinctiveness of these strains has been confirmed via microsatellites (Skaala et al. 2004) and allozyme markers (Skaala et al. 2005). These authors concluded that a combination of founder effects and genetic drift represent the major forces driving development of large and distinct molecular genetic differences among strains.

In light of the fact that Norwegian Atlantic salmon aquaculture is based on fish from a limited number of strains, it could be reasoned (and was by some) that use of DNA methods to trace escaped salmon back to the farm of origin would not be successful in most cases. While it is true that some farms within a given region do indeed rear fish originating from the same strain(s), sometimes resulting in overlapping allele frequencies among cages of fish on neighboring farms (Glover et al. 2008, unpubl.), the distribution of genetic material from the breeding programs to marine cage producers is complicated (Fig. 2). It was first hypothesised (Glover et al. 2008, 2009b) that distribution of genetic material from the breeding programs to marine cages, via egg, fry and smolt producers, may permit the development of a greater number of genetically distinct groups of salmon than strains through the process of genetic drift. This was confirmed by a study of 


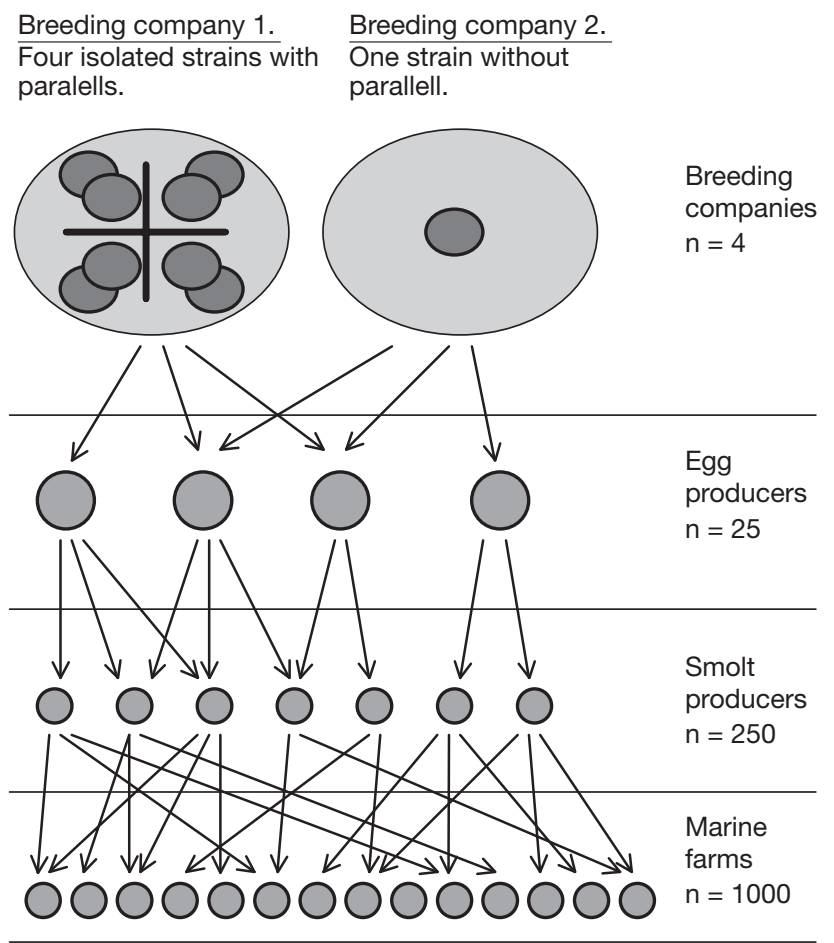

Fig. 2. Supply chain for production of Atlantic salmon Salmo salar in Norwegian aquaculture. Arrows indicate movements of eggs, fry and smolts between the different stages of production. It is important to note that the diagrams illustrate the potential complexity of the supply chain rather than depicting exact movements. Approximate number of licenses (n) given for 2009

genetic variation in cages of salmon originating from a single breeding company (K. A. Glover unpubl.). The authors observed genetically identifiable groups within a single year class, and concluded this was possible as batches of eggs (often resulting from limited numbers of parents), fry and smolts tend not to be mixed in the production chain from breeder to sea farm. This is in part due to considerations such as the transfer of disease, traceability of own production, and the fact that the next link in the production chain may also request knowledge of origin. Consequently, the number of genetically identifiable groups reared in fish cages is greater than the number of strains or breeding programs, permitting increased opportunity for identification. Genetic drift within domestic populations is well documented (Cross \& King 1983, Verspoor 1988, Perez et al. 2001) and clearly plays an important role in the success of the stand-by method.

\section{Implementation of a DNA register}

The use of DNA registers to monitor harvest and trade of endangered and protected wildlife and their derived products is gaining increasing international attention (Baker 2008). For example, fully or partially complete genetic databases (of allele frequencies or individual genetic profiles) have been used to monitor trade in whale meat (Palsboll et al. 2006), illegal trade in African elephant ivory (Wasser et al. 2008), in addition to mixed stock analysis for fishery management in the Pacific (Withler et al. 2004).

A range of statistical programs exist (Duchesne et al. 2002, Taggart 2007) to assign parentage to offspring in mixed family environments where known crosses have been established (Glover et al. 2004) and in mixed family environments where parental genotypes are known but individual crosses have not been documented (Herlin et al. 2007, 2008). With even modest numbers of loci, it is possible to identify individuals back to large numbers of families. For example, simulations conducted on a mass spawning tank for Atlantic cod containing a potential of 2717 families revealed unambiguous assignment of 88.8 and $92.1 \%$ of the offspring using 5 and 8 polymorphic microsatellite markers, respectively (Herlin et al. 2008).

Whereas the DNA stand-by method implements a 'bottom-up' approach to identification, i.e. starting with DNA of escapees and sampling the last plausible link within the supply chain to identify/exclude the potential escapement source(s), a 'top-down' approach to identification, using a DNA register, has also been considered. A DNA register consisting of allele frequencies for a panel of molecular genetic markers for the major strains would incur problems due to genetic drift from the breeding programs to commercial production (Fig. 2, discussion above). However, a DNA register could consist of a combination of breeding information and individual DNA profiles in order to permit the identification of escapees through match/exclusion to family (as described above). The DNA register would need to be combined with rigorous documentation of fish movements across the supply chain, perhaps combined with genotyping tests of proficiency. A register could provide some advantages over the DNA stand-by method that a physical tag could also provide (Table 1), notably, diagnostic identification of escapees, even in the case of drip-leakage, and an indefinite time delay following escapement. While a DNA register approach is technically viable, and feasible within the logistical framework of individual producers who require a verification tool for monitoring and tracing their own production, for management authorities requiring an identification tool for farm escapees for the entire industry, this approach presents major, and arguably insurmountable, logistical challenges.

A major problem with the DNA register approach is that alone it cannot assign ownership to individual fish. For example, if a $0.5 \mathrm{~kg}$ escapee is found in the sea, 
and identified to family, it is not possible to demonstrate whether it was the smolt producer or the sea farm that was responsible for the loss. In order to circumvent this challenge, the sampling logistics described for the stand-by method above would need to be applied, and some of the potential advantages of the register are therefore eliminated. In addition, the total annual production of fertilised Atlantic salmon eggs in Norwegian aquaculture is estimated to be in excess of 500 million (T. A. Helle, NDF, pers. comm.). Given an average of 10000 eggs yield per female, this equates to >50 000 females spawned each year. Maintaining a database containing this number of fish and documenting fish-family movements between the various producers would be technically challenging. As in the case of physical tagging, it would also incur high costs for fish that do not escape.

\section{Other species and supplementary methods}

The structure of Norwegian breeding programs for rainbow trout and Atlantic cod are not as well documented as for Atlantic salmon; however, these species offer contrasting aquaculture situations. First, rainbow trout has a very long history of domestication (MacCrimmon 1971, Gall \& Crandell 1992), and farmed rainbow trout in Europe originate from a low number of sources. This is likely to have reduced levels of genetic variation before the Norwegian breeding programs were established, and due to the low number of sources from which rainbow trout originate, may have reduced potential for genetic divergence between the commercial strains. Second, Atlantic cod is not considered to constitute a domesticated species, and most Norwegian breeding programs are currently only in their second generation. Furthermore, use of wild adults as a broodfish supplement is still practiced for some strains. Nevertheless, distinct genetic differences have been reported among many of the Norwegian rainbow trout strains, permitting the opportunity for genetic identification (Glover 2008), and significant genetic differences between cages of Atlantic cod arising from different strains have been reported (Glover et al. in press). Consequently, these studies demonstrate that the bottom up approach adopted by the stand-by method is not only effective in the identification of farm-escaped Atlantic salmon in Norway, where it has been implemented repeatedly, but it is universally applicable for a wide range of aquaculture species where identification is required.

The DNA stand-by method has thus far been implemented in identification of farm escapees for species where there are morphological characteristics separating wild and farmed conspecifics. In Atlantic salmon, for example, scale reading and external body morphology (Lund et al. 1991), vaccine marks (Lund et al. 1997) and scale chemistry (Adey et al. 2009) all may play a significant role in identifying fish captured in the wild as farm escapees. For aquaculture species reared outside their native range or in regions where the presence of wild conspecifics is seasonal, distinct morphological characteristics to identify escapees may not be required. In regions where farmed and wild conspecifics overlap in time and space, but lack universal diagnostic morphological characteristics, the DNA stand-by method can still be implemented. By genetic analysis of both putatively identified recaptured escapees and wild fish captured at the same time and in the same area, it is possible to treat wild fish as a potential source for the putatively identified escapes, just as one treats farm samples, and assign/exclude the potential escapees from all sources.

As reported, the DNA stand-by method is unlikely to be able to identify a single source of escapement in every case. Although exclusion of many sources permits fishery officers to inspect a limited number of farms, the use of non-genetic supplementary identification methods, to increase precision, may play an increasing role in the future. For example, both fatty acid profiling of fish scales (Grahl-Nielsen \& Glover in press) and scale microchemistry (Adey et al. 2009) have been demonstrated to differ between groups of Atlantic salmon reared on adjacent farms. In situations where DNA identification cannot make a fully diagnostic identification, it is possible that non-genetic supplementary methods can assist. In addition, chemical agents to delouse fish for Lepeophtheirus salmonis may play an important supplementary role in identification of source in regions where farms do not display synchronous delousing and/or where farms use different chemicals. The half-life of delousing agent residues also has the potential to assist in determining the time of escapement.

\section{CONCLUSIONS}

The DNA stand-by method represents a significant advance in identification of source for fish farm escapees. Its suitability for implementation with Atlantic salmon, rainbow trout and Atlantic cod in Norwegian aquaculture demonstrates that the method can potentially be applied for identification of fish farm escapees for a wide range of species across the world. The method has permitted Norwegian authorities to monitor aquaculture production and, where necessary, fine companies in breach of regulations. However, it is ultimately hoped that the method's existence will encourage a higher reporting frequency from farmers. 
Acknowledgements. We thank 3 anonymous referees for helpful comments on an earlier draft of this manuscript. Dr. John B. Taggart of the University of Stirling, Scotland, is acknowledged for his contribution to the design of the DNA stand-by method. Dr. Øystein Skaala from the Institute of Marine Research, Norway, is acknowledged for managing the Norwegian research council funded project TRACES, where the identification method was initially developed. Both Dr. Øystein Skaala and Dr. Terje Svåsand from the Institute of Marine Research made comments on earlier drafts of this paper. This work was financed by the Norwegian Department of Fisheries and the Institute of Marine Research.

\section{LITERATURE CITED}

Adey EA, Black KD, Sawyer T, Shimmield TM, Trueman CN (2009) Scale microchemistry as a tool to investigate the origin of wild and farmed Salmo salar. Mar Ecol Prog Ser 390:225-235

Anonymous (2007) Scottish fish farms annual production survey 2007. Fisheries Research Services, Marine Laboratory, Aberdeen; www.marlab.ac.uk/FRS.Web/Uploads/ Documents/surveytext2007final.pdf.

Baarøy V, Gjerde B, Heggberget TG, Jensen PE, Maroni K, Sandvik S, Skaala Ø (2004) Identifisering av rømt oppdrettlaks. Utredning av utvalg nedsatt av Fiskeridirektøren (Identification of escaped farmed salmon. Report from the Committee to the Director of Fisheries). (in Norwegian); http://fiskeridir.no

Baker CS (2008) A truer measure of the market: the molecular ecology of fisheries and wildlife trade. Mol Ecol 17: 3985-3998

Brennan NP, Leber KM, Blackburn BR (2007) Use of codedwire and visible implant elastomer tags for marine stock enhancement with juvenile red snapper Lutjanus campechanus. Fish Res 83:90-97

Bumgarner JD, Schuck ML, Blankenship HL (2009) Returns of hatchery steelhead with different fin clips and coded wire tag lengths. N Am J Fish Manag 29:903-913

> Campana SE, Joyce W, Manning MJ (2009) Bycatch and discard mortality in commercially caught blue sharks Prionace glauca assessed using archival satellite pop-up tags. Mar Ecol Prog Ser 387:241-253

Clifford SL, McGinnity P, Ferguson A (1998a) Genetic changes in an Atlantic salmon population resulting from escaped juvenile farm salmon. J Fish Biol 52:118-127

> Clifford SL, McGinnity P, Ferguson A (1998b) Genetic changes in Atlantic salmon (Salmo salar) populations of northwest Irish rivers resulting from escapes of adult farm salmon. Can J Fish Aquat Sci 55:358-363

Cookingham MN, Ruetz CR (2008) Evaluating passive integrated transponder tags for tracking movements of round gobies. Ecol Freshw Fish 17:303-311

> Cross TF, King J (1983) Genetic effects of hatchery rearing in Atlantic salmon. Aquaculture 33:33-40

> Crozier WW (1993) Evidence of genetic interaction between escaped farmed salmon and wild Atlantic samon (Salmo salar L.) in a northern Irish river. Aquaculture 113:19-29

Crozier WW (2000) Escaped farmed salmon, Salmo salar L., in the Glenarm River, Northern Ireland: genetic status of the wild population 7 years on. Fish Manag Ecol 7:437-446

Duchesne P, Godbout MH, Bernatchez L (2002) PAPA (package for the analysis of parental allocation): a computer program for simulated and real parental allocation. Mol Ecol Notes 2:191-193

Falush D, Stephens M, Pritchard JK (2003) Inference of popu- lation structure using multilocus genotype data: linked loci and correlated allele frequencies. Genetics 164: $1567-1587$

Fleming IA, Einum S (1997) Experimental tests of genetic divergence of farmed from wild Atlantic salmon due to domestication. ICES J Mar Sci 54:1051-1063

Fleming IA, Hindar K, Mjolnerod IB, Jonsson B, Balstad T, Lamberg A (2000) Lifetime success and interactions of farm salmon invading a native population. Proc R Soc Lond Ser B Biol Sci 267:1517-1523

> Fleming IA, Agustsson T, Finstad B, Johnsson JI, Bjornsson BT (2002) Effects of domestication on growth physiology and endocrinology of Atlantic salmon (Salmo salar). Can J Fish Aquat Sci 59:1323-1330

Frantz AC, Pourtois JT, Heuertz M, Schley L and others (2006) Genetic structure and assignment tests demonstrate illegal translocation of red deer (Cervus elaphus) into a continuous population. Mol Ecol 15:3191-3203

Gall GAE, Crandell PA (1992) The rainbow trout. Aquaculture 100:1-10

Gjedrem T, Gjoen HM, Gjerde B (1991) Genetic origin of Norwegian farmed Atlantic salmon. Aquaculture 98:41-50

Glover KA (2008) Genetic characterisation of farmed rainbow trout in Norway: intra- and inter-strain variation reveals potential for identification of escapees. BMC Genet 9:87

Glover KA, Taggart JB, Skaala O, Teale AJ (2004) A study of inadvertent domestication selection during start-feeding of brown trout families. J Fish Biol 64:1168-1178

Glover KA, Skilbrei OT, Skaala O (2008) Genetic assignment identifies farm of origin for Atlantic salmon Salmo salar escapees in a Norwegian fjord. ICES J Mar Sci 65:912-920

- Glover KA, Hansen MM, Skaala O (2009a) Identifying the source of farmed escaped Atlantic salmon (Salmo salar): Bayesian clustering analysis increases accuracy of assignment. Aquaculture 290:37-46

Glover KA, Ottera H, Olsen RE, Slinde E, Taranger GL, Skaala O (2009b) A comparison of farmed, wild and hybrid Atlantic salmon (Salmo salar L.) reared under farming conditions. Aquaculture 286:203-210

Glover KA, Dahle G, Westgaard JI, Johansen T, Knutsen H, Jørstad KE (2010a) Genetic diversity within and among Atlantic cod (Gadus morhua) farmed in marine cages: a proof-of-concept study for the identification of escapees. Anim Genet (in press)

Glover KA, Hansen MM, Lien S, Als TD, Høyheim B, Skaala O (2010b) A comparison of SNP and STR loci for delineating population structure and performing individual genetic assignment. BMC Genet 11:2

Grahl-Nielsen O, Glover KA (2010) Fatty acids in fish scales. Mar Biol (in press)

> Hansen LP, Reddin DG, Lund RA (1997) The incidence of reared Atlantic salmon (Salmo salar L) of fish farm origin at West Greenland. ICES J Mar Sci 54:152-155

Hansen MM, Kenchington E, Nilsen EE (2001) Assigning individual fish to population using microsatellite DNA markers. Fish Fish 2:93-112

Herlin M, Taggart JB, McAndrew BJ, Penman DJ (2007) Parentage allocation in a complex situation: a large commercial Atlantic cod (Gadus morhua) mass spawning tank. Aquaculture 272:S195-S203

> Herlin M, Delghandi M, Wesmajervi M, Taggart JB, McAndrew BJ, Penman DJ (2008) Analysis of the parental contribution to a group of fry from a single day of spawning from a commercial Atlantic cod (Gadus morhua) breeding tank. Aquaculture 274:218-224

> Hindar K, Fleming IA, McGinnity P, Diserud A (2006) Genetic and ecological effects of salmon farming on wild salmon: 
modelling from experimental results. ICES J Mar Sci 63: $1234-1247$

Jackson TR, Martin-Robichaud DJ, Reith ME (2003) Application of DNA markers to the management of Atlantic halibut (Hippoglossus hippoglossus) broodstock. Aquaculture 220:245-259

- Johnsson JI, Hojesjo J, Fleming IA (2001) Behavioural and heart rate responses to predation risk in wild and domesticated Atlantic salmon. Can J Fish Aquat Sci 58:788-794

Lund RA, Okland F, Hansen LP (1991) Farmed Atlantic salmon (Salmo salar L.) in fisheries and rivers in Norway. Aquaculture 98:143-150

Lund RA, Midtlyng PJ, Hansen LP (1997) Post-vaccination intra-abdominal adhesions as a marker to identify Atlantic salmon, Salmo salar L., escaped from commercial fish farms. Aquaculture 154:27-37

MacCrimmon H (1971) World distribution of rainbow trout (Salmo Gairdneri). J Fish Res Board Can 28:663\&

Manel S, Gaggiotti OE, Waples RS (2005) Assignment methods: matching biological questions techniques with appropriate. Trends Ecol Evol 20:136-142

McAllister KW, McAllister PE, Simon RC, Werner JK (1992) Performance of 9 external tags on hatchery-reared rainbow trout. Trans Am Fish Soc 121:192-198

McGinnity P, Stone C, Taggart JB, Cooke D and others (1997) Genetic impact of escaped farmed Atlantic salmon (Salmo salar L.) on native populations: use of DNA profiling to assess freshwater performance of wild, farmed, and hybrid progeny in a natural river environment. ICES J Mar Sci 54:998-1008

McGinnity P, Prodohl P, Ferguson K, Hynes R and others (2003) Fitness reduction and potential extinction of wild populations of Atlantic salmon, Salmo salar, as a result of interactions with escaped farm salmon. Proc R Soc Lond Ser B Biol Sci 270:2443-2450

Milner NJ, Evans R (2003) The incidence of escaped Irish farmed salmon in English and Welsh rivers. Fish Manag Ecol 10:403-406

- Norris AT, Bradley DG, Cunningham EP (1999) Microsatellite genetic variation between and within farmed and wild Atlantic salmon (Salmo salar) populations. Aquaculture 180:247-264

Ogden R (2008) Fisheries forensics: the use of DNA tools for improving compliance, traceability and enforcement in the fishing industry. Fish Fish 9:462-472

Palsboll PJ, Berube M, Skaug HJ, Raymakers C (2006) DNA registers of legally obtained wildlife and derived products as means to identify illegal takes. Conserv Biol 20: $1284-1293$

Perez LA, Winkler FM, Diaz NF, Carcamo C, Silva N (2001) Genetic variability in four hatchery strains of coho salmon, Oncorhynchus kisutch (Walbaum), in Chile. Aquacult Res 32:41-46

Powell J, White I, Guy D, Brotherstone S (2008) Genetic parameters of production traits in Atlantic salmon (Salmo salar). Aquaculture 274:225-231

Primmer CR, Koskinen MT, Piironen J (2000) The one that did

Editorial responsibility: Dean Jerry,

Townsville, QLD, Australia not get away: individual assignment using microsatellite data detects a case of fishing competition fraud. Proc R Soc Lond Ser B Biol Sci 267:1699-1704

> Rasmussen RS, Morrissey MT (2008) DNA-based methods for the identification of commercial fish and seafood species. Compr Rev Food Sci Food Saf 7:280-295

Roberge C, Einum S, Guderley H, Bernatchez L (2006) Rapid parallel evolutionary changes of gene transcription profiles in farmed Atlantic salmon. Mol Ecol 15:9-20

Roberge C, Normandeau E, Einum S, Guderley H, Bernatchez L (2008) Genetic consequences of interbreeding between farmed and wild Atlantic salmon: insights from the transcriptome. Mol Ecol 17:314-324

> Shroyer SM, Logsdon DE (2009) Detection distances of elected radio and acoustic tags in Minnesota lakes and rivers. N Am J Fish Manag 29:876-884

Skaala O, Hoyheim B, Glover K, Dahle G (2004) Microsatellite analysis in domesticated and wild Atlantic salmon (Salmo salar L.): allelic diversity and identification of individuals. Aquaculture 240:131-143

> Skaala O, Taggart JB, Gunnes K (2005) Genetic differences between five major domesticated strains of Atlantic salmon and wild salmon. J Fish Biol 67:118-128

Skaala O, Wennevik V, Glover KA (2006) Evidence of temporal genetic change in wild Atlantic salmon, Salmo salar L., populations affected by farm escapees. ICES J Mar Sci 63:1224-1233

Skilbrei OT, Wennevik V (2006) The use of catch statistics to monitor the abundance of escaped farmed Atlantic salmonand rainbow trout in the sea. ICES J Mar Sci 63:1190-1200

Taggart JB (2007) FAP: an exclusion-based parental assignment program with enhanced predictive functions. Mol Ecol Notes 7:412-415

Thodesen J, Grisdale-Helland B, Helland SJ, Gjerde B (1999) Feed intake, growth and feed utilization of offspring from wild and selected Atlantic salmon (Salmo salar). Aquaculture 180:237-246

> Verspoor E (1988) Reduced genetic variability in 1st-generation hatchery populations of Atlantic salmon (Salmo salar L.). Can J Fish Aquat Sci 45:1686-1690

> Walker AM, Beveridge MCM, Crozier W, Ó Maoiléidigh N, Milner N (2006) Monitoring the incidence of escaped farmed Atlantic salmon, Salmo salar L., in rivers and fisheries of the United Kingdom and Ireland: current progress and recommendations for future programmes. ICES J Mar Sci 63:1201-1210

- Wasser SK, Clark WJ, Drori O, Kisamo ES, Mailand C, Mutayoba B, Stephens M (2008) Combating the illegal trade in African elephant ivory with DNA forensics. Conserv Biol 22:1065-1071

Webb JH, Hay DW, Cunningham PD, Youngson AF (1991) The spawning behavior of farmed and wild adult Atlantic salmon (Salmo salar L.) in a northern Scottish river. Aquaculture 98:97-110

Withler RE, Candy JR, Beacham TD, Miller KM (2004) Forensic DNA analysis of Pacific salmonid samples for species and stock identification. Environ Biol Fishes 69:275-285

Submitted: January 4, 2010; Accepted: March 8, 2010

Proofs received from author(s): March 25, 2010 